\title{
The rise of BRICS: implications for global agrarian transformation
}

\author{
Ben M. McKay, Ruth Hall and Juan Liu
}

\begin{abstract}
This article introduces this collection, which focuses on the economic and political rise of the BRICS countries (Brazil, Russia, India, China, and South Africa) and its implications for global agrarian transformation. These emerging economies are undergoing profound changes as key sites of the production, circulation, and consumption of agricultural commodities; hosts to abundant cheap labour and natural resources; and home to growing numbers of both poor but also, increasingly, affluent consumers. Separately and together these countries are shaping international development agendas both as partners in, and potential alternatives to, the development paradigms promoted by the established hubs of global capital in the North Atlantic and by dominant international financial institutions. Collectively, the findings show the significance of BRICS countries in reshaping agro-food systems at the national and regional level, and their global significance. As they export their own farming and production systems across different contexts, though, the outcomes are contingent and success is not assured. At the same time, BRICS may represent a continuation rather than an alternative to the development paradigms of the Global North.
\end{abstract}

\section{Introduction}

Profound agrarian changes are underway in emerging economies such as Brazil, Russia, India, China, and South Africa (BRICS). These vary from land concentration, changing ruralurban linkages, migration, the rise of corporate agribusiness, contract farming schemes for smallholders, class differentiation between smallholders, family farmers, and labourers, new forms of agri-businesses upstream and downstream of farming, vertical (and horizontal) integration in value chains, and supermarketisation. Such agrarian transformations in turn interact with changes in the rural societies and agrarian economies in neighbouring countries as BRICS countries expand their presence in their respective regions through both state and private sector-led partnerships and investment deals. These transformations do not represent simply the extension of BRICS countries into their respective regions, where they are playing important roles as regional powers. Rather, their roles interact with dynamic changes already underway within these regions, marked partly by the rise of another set of powerful actors: Middle Income Countries (MICs) like Argentina, Chile, and Peru in South America; Indonesia, Malaysia, Thailand, and Vietnam in Southeast Asia; and Kenya and Nigeria in Africa. 
The rise of BRICS countries alongside some powerful MICs, and the emerging alliances within and between them, has sparked debate about whether they herald a new era in the global political economy as an alternative to the conventional North Atlantic-anchored neoliberal prescriptions for development - or whether their models of development are problematic, in similar or perhaps new ways. ${ }^{1}$ More profoundly, the BRICS countries challenge existing conceptions of a North-South divide as the most significant dimension of global inequality in power and wealth, but without challenging capitalism as a system, or seeking to fundamentally transform the underlying social relations of capitalist agricultural production. This presents new challenges and opportunities for scholars, activists, policymakers, development practitioners, and others. Agro-food system change and agrarian dynamics need to be understood in what seems to be an evolving polycentric world order and new and innovative initiatives in knowledge production are required in response.

In addressing this research challenge, it is important to build on and extend the focus of existing knowledge about BRICS and MICs. The rise of BRICS countries and MICs has been accompanied by the emergence of new spheres of research, academic dialogue, and exchange in recent years. Most of these initiatives are BRICS-oriented and Africa-centred, tracking the impact of, mainly, China and Brazil on Africa. ${ }^{2}$ Many of these studies are from international relations and international political economy traditions, with much less engagement by researchers from agrarian political economy. This body of emerging literature has provided us with important perspectives, but there remain key themes which are under-explored, including their influence in their respective regions. This present collection contributes to building a new literature with a particular focus on the emerging dynamics and implications for agrarian change.

This collection of essays emerges from the BRICS Initiatives in Critical Agrarian Studies (BICAS), which is a collective of academic researchers largely based within BRICS countries themselves. Scholars in the network are concerned with understanding the implications of the rise of emerging economies for national, regional, and global agrarian transformations. This collection contributes to the BICAS agenda, with the aim not only of contributing to understanding new dynamics of agrarian change but also to promoting further research and dialogue. It addresses, to various extents, four thematic research clusters with reference to Brazil, Russia, China, and South Africa. Unfortunately, this collection does not feature an analysis into the agrarian dynamics within India nor the influence of Indian capital elsewhere - an omission to hopefully be addressed as the network expands.

The four themes addressed are: (i) national agrarian dynamics within BRICS countries; (ii) BRICS countries and intra-regional agrarian transformations; (iii) new dynamics and multiple centres of power in the agro-food system; and (iv) BRICS and MICs in relation to the old hubs of global capital. The remainder of this introductory article introduces these four research clusters as well as outlining the contributions of the individual papers within this collection. However, many articles address issues related to multiple research clusters in complementary and overlapping ways. The rise of BRICS countries and its implications for global agrarian 
transformation represents a huge topic of research. This collection in no way provides a complete nor comprehensive analysis into all of these new and changing dynamics. Rather, it hopes to make a contribution to the much larger and ongoing research global initiative of BICAS3, with the intention of encouraging other researchers to deepen enquiry and theorisation in this field.

\section{National agrarian dynamics}

Rather than engaging with BRICS as a political-economic bloc or organisation, 4 this collection addresses the BRICS countries themselves and the changes underway within their national territories, in their respective regions, and their emerging political and economic relations and activities in other regions. Several essays in this collection provide in-depth analyses into the agrarian dynamics and transformations within BRICS countries themselves. It is crucial to understand the agrarian, food and environmental changes taking place within these emerging economies in order to further understand the broader implications for global agrarian transformation.

In this collection, Andrade analyzes the rise of Brazil as a global agribusiness power and the overall transformations of production, trade, and capital flows which have emerged since the neoliberal reforms in the 1990s.5 She argues that the macroeconomic policies which deregulated the national economy and opened it up to financial speculation have undermined the industrial sector, leading to a reprimarization of the economy and particularly the country's exports. This was not only due to the global commodities boom nor the increased demand for primary commodities from China, but also 'the outcome of policy-induced constraints on production?. 6 Andrade provides an explanation as to the core of the crisis that erupted in Brazil in 2014, linking it to Brazil's rise as a global agribusiness power and the country's insertion into global circuits of financial capital accumulation resulting in, and even concealing, an overall loss of economic power and political autonomy. The Brazilian agricultural development model has been promoted, for instance, by development agencies and international financial institutions, as one to replicate, not only in Latin America but also in Africa.7 However, Andrade's analysis should caution those governments looking to reproduce such a model, by drawing attention to the vulnerabilities that arise from financial speculation in the agricultural sector.

In their analysis of national agrarian dynamics within Russia, Nikulin and Trotsuk revive the utopian visions of rural-urban reciprocity that were articulated in the work of the key Russian agrarian thinker, A.V. Chayanov, in the early twentieth century. 8 They argue that Chayanov's work offers important insights into understanding contemporary agrarian transformations in Russia and the world. Nikulin and Trotsuk reveal the diversity of Russia's agrarian pathways and the various agricultural'worlds' which coexist. Moscow and Saint Petersburg continue to expand, absorbing rural territory and skilled labour and, perhaps paradoxically, have become the centre of agricultural production through giant agro-holdings. While it appears that mega-cities are pulling in capital, labour, and land, the authors point to the 
Belgorod region as a counterexample of what can transpire when Chayanov's neopopulist ideas are put into practice. Belgorod's development model is one based on a symbiotic relationship between the rural and urban, agricultural and industry, tradition and modernity. It is highlighted as a successful mixed economy with high rates of economic growth and quality of life. Despite the overall urban and agro-industrial bias throughout the country, the authors argue that elements of Chayanov's utopian insights can - and should - be applied, not only to understand but also to influence new trajectories of agrarian change.

Across the literature, there are contested interpretations of agricultural commercialisation and what constitute 'success stories' - whether in the Brazilian Cerrado, Russian massive agroholdings or India's Special Economic Zones (SEZs). 9 These contestations centre on what constitutes positive agrarian outcomes but also on how the real economy and speculation interact. While dominant development institutions continue to promote large-scale industrial agriculture, critical studies have pointed to its accelerating biophysical contradictions ${ }^{10}$, while others reveal the very extractive character - socially, economically, and environmentally - of this agricultural development model. ${ }^{11}$ The papers in this collection also show the social, cultural, and economic implications of the dominant model of agricultural development and that alternatives to large-scale and corporatist production and value-chain concentration can and do exist, and that can be learnt from these experiences.

\section{Intra-regional agrarian transformation}

As political and economic powers in their respective regions, the rise of BRICS countries has significant implications for agrarian transformation intra-regionally. This includes both capital and labour flows in and around these new hubs of global capital accumulation, and land concentration or 'land grabbing' across national boundaries. ${ }^{12}$ Brazil, for example, has led the way in agro-industrial development in the Latin American region, spreading not only its technologies and expertise but also capital investment, with Brazilian farmers moving to and investing in land, most prominently in Paraguay and Bolivia. ${ }^{13}$ In Africa, South African capital and farmers are extending their reach throughout the continent - going beyond agriculture to construction and infrastructure and leading to a concentration of control over land, labour, and capital. 14

In this collection, Martiniello uses a case study of South African sugar giant Illovo's acquisition of Kilombero Sugar Company Limited in Tanzania to explore the socioecological implications of such large-scale agricultural investments. ${ }^{15}$ While contract farming and out-grower schemes have been promoted by influential development institutions such as the World Bank, Martiniello reveals how small-scale farmers became adversely incorporated into the agro-industrial value-chain by means of this outgrower scheme. Rather than protecting outgrowers against market risk, he shows how the scheme exposed small farmers to the risks and oscillations of volatile market prices and low harvests and 'have been used as an instrument to optimise the capacity utilisation of mills, and as a buffer against risks of under-production.16 Martiniello's case study 
illuminates the more generalisable trends of what Hall calls the'South Africanisation' of the region which, as she explains, is 'not in the literal sense of South Africa becoming the coloniser of the region (though elements of that view may indeed betrue!) but rather in the sense that the changes underway - concentration of control over land, labour and value chains (capital) - are rendering the agrarian structure of several countries more like that of a settler state like South Africa.' 17

In Asia, too, significant intra-regional agrarian transformations can be observed, due in many instances to the infl e of China in the region, especially related to land grabbing, crop booms inside China and other investments in South-East Asia. ${ }^{18}$ In this collection, Zhou reveals how Chinese labourers - faced with a scarcity of arable land and labour opportunities - are migrating to the Russian Far East (RFE) where land is cheap and abundant. ${ }^{19}$ Chinese investors are also looking to the RFE for business opportunities, investing in farmland, and forming joint ventures with Russian agribusinesses. Zhou argues that both Chinese capital and Chinese labour have revived, in different ways, agricultural production in the RFE, contributing to Russia's food security and offering both capital and labour absorption for otherwise idle or surplus factors of production in China. Zhou illustrates the capitalist dynamics of agrarian change 'from above' and 'from below' in the RFE as Chinese peasants, wage labourers, entrepreneurs, large-scale enterprises, and state-owned farms have looked to their Russian neighbours for farming and investment opportunities.

These papers draw attention to the diverse ways in which agrarian conditions within BRICS countries condition how they influence agrarian dynamics within their respective regions. Intra-regional impacts vary from land and agribusiness deals to labour migration in fact, transnational shifts are evident in agro-food systems, from inputs to production to processing. The mobility of capital and labour combine in different ways, driven by both pull and push factors, involving multiple actors and stakeholders, and have diverse effects on neighbouring countries. Simplistic narratives of BRICS countries being neo-imperialists within their spheres of influence clearly do not capture the complexities these contributions draw attention to.

\section{New dynamics and multiple centres of power}

Beyond national and regional changing dynamics, the rise of BRICS and MICs has led to the emergence of what some scholars are calling a 'polycentric' food regime. This refers to the 'multiple centres of power, and a more diverse range of key international actors within the governance structure of the food-energy complex, both sectorally and geopolitically', in contrast to the North Atlantic-dominated food regimes of the past. ${ }^{20}$ Now, not only the traditional powers of the global North but also BRICS and MICs play key roles in the changing dynamics in the patterns of production, consumption, and distribution of the agro-food system. Brazil and China in particular have become key sites for the production and consumption of agro-commodities, as new players (both public and private) have emerged within these countries, reshaping the implicit and explicit rules and regulations which structure agro-food relations on a global scale. ${ }^{21}$ Multinationals from the North Atlantic 
such as ADM, Bunge, Cargill, and Louis Dreyfus (ABCD) still dominate the global grain trade, but Brazilian and Argentinian agribusiness firms are expanding their reach in Latin America largely through pools de siembra (sowing pools). ${ }^{22}$ Furthermore, China's stateowned national Cereals, Oils, and Foodstuffs Co. (COFCO) has become a new global agribusiness giant, as also discussed by McKay et al. and Wilkinson et al. in this collection. 23

Also in this collection, Campbell explores new dynamics in Sub-Saharan Africa's agro-food system and the role South African capital is playing in the region. 24 She provides an overview of South Africa's supermarket expansion across the continent - from East Africa, West Africa to Central Africa. This is associated in part with the growth of an urban middle class and growing consumer base. While sub-regional variations are certainly present, Campbell argues that South African supermarket expansion is reshaping relations of production, distribution, and consumption through a model of corporate food retail which excludes or at best marginalises local small-scale farmers. The supermarket revolution is leading to new relations of dependency on cheap manufactured food items from external markets (much of it imported from South Africa), while corporate-controlled value-chains exclude small-scale farmers, even in the fresh produce sector, by means of economies of scale and industry-specific production standards. However, such processes have not gone uncontested, as Campbell points to forms of resistance to'supermarketisation'across the region. While South Africa's food retailers may be leading the process of 'supermarketisation', it has also opened the doors to larger multinational corporations and a concentration of control over the food system throughout the region.

Yet, while flows of capital and labour are moving from emerging economies throughout their regions, the implications for agrarian change go beyond capital and labour flows. Milhorance provides insights into the policy coalitions which facilitate the adoption and expansion of the Brazilian agribusiness model, not only across Latin America but also, through South-South cooperation, to the African continent. Policy-makers, bureaucrats, researchers, and corporate actors from Brazil promote the transfer of knowledge and Brazilian expertise in several African countries, which in turn requires financial, technical, and political resources in order to emulate its model of agricultural development. Milhorance asserts that such policy networks indirectly facilitate the expansion of Brazil's agro-industry into foreign markets. The adoption of technologies, new forms of production, norms, and standards based on the Brazilian experience reinforces its position as a global agribusiness power, forming the 'foundations upon which investments and commodity trade are built'.25 With important insights from key informants, Milhorance points to the underlying motives of the growing South-South agribusiness connections between Brazil and Southern Africa.

These new dynamics in global agro-food relations represent a shift from North Atlantic dominance to a more polycentric food system. Emerging economies have become key sites for agro-commodity production and consumption, no longer dependent on North Atlantic capital or markets. Yet this is not merely a matter of reproducing production systems, value 
chains, and wider agro-food systems. These are not easily transposed across diverse economic, social, and agro-ecological contexts. As shown by the contributions presented here, such expansion encounters competition and even, at times, failure. Therefore, the outcomes of BRICS and MICs and their expansionary ambitions are uncertain and contingent.

\section{BRICS, MICs, and old hubs of global capital}

Lastly, this collection analyses the rise of emerging economies in relation to the old hubs of global capital, represented by North America and Europe. BRICS and MICs are now key players in global trade in food and agro-commodities as new political and economic relations are taking shape around the world. Neoliberal policies and the 'Washington Consensus' which prevailed as the dominant ideology during the last decade of the twentyfirst century have been largely discredited as many developing countries (most predominantly in Latin America) seek to distance themselves from US market and policy dependence. ${ }^{26}$ The political and economic rise of BRICS and MICs, and the financial crises of the past decade and associated recession in the old hubs, have shifted the global political economy. New alliances and the reassertion of the role of the state in development among these rising powers are now also shaping international development agendas. 27

Over the past decade, China-Latin America relations have exploded - in terms of trade, finance, and investment. McKay et al. explore the implications of such new economic and political relations in terms of agrarian transformation in Latin America. ${ }^{28}$ This contribution analyses China's 'going out' policy and the geopolitical shifts which have led to the growth of Latin America's soy complex. With a focus on Argentina and Brazil, McKay et al. question such emerging partnerships and the notion of South-South cooperation, arguing that the massive expansion of China-Latin America trade in agro-food commodities continues to reinforce similar relations of production and resource control based on a model of extractivism which has plagued the region's industrial development for decades. Rather than BRICS trade presenting a new developmental path, it appears to be reinforcing the old.

Wilkinson et al. similarly analyse the growing agribusiness connections between China, Brazil, and the Southern Cone countries (Argentina, Paraguay and Uruguay) more generally, highlighting China's'more-than-market'strategy to secure control over raw materials. ${ }^{29}$ They show how China has replaced the European Union as Brazil's principal market for agribusiness exports by going beyond trade to more direct negotiation, partnerships, and joint ventures. They contend that China's activity in the Southern Cone can be divided into four phases: (i) land acquisition or'land grabbing'; (ii) formal negotiations with national- and provincial-level governments; (iii) large-scale infrastructure investments to improve Brazil's export logistics; and (iv) directly competing for control over the global grain trade. This contribution delves into the new strategies and policies which have facilitated relations among these new hubs of global capital, revealing how China is positioning itself as a major player in the global grain trade. 
All this suggests that there has been a'thickening'of trade among BRICS countries themselves, not only due to particular commodity booms but also facilitated by trade deals bilaterally and within the group as a whole. Together and separately, these emerging political and economic powers are increasingly challenging the old hubs of global capital in the North Atlantic as they consolidate themselves as new sites of global capital accumulation, circulation, and consumption, promoted by discourses of SouthSouth'cooperation. As the papers in this collection reveal, however, the extent to which such new relations and partnerships challenge, or represent alternatives to, dominant development paradigms regarding the social relations of production, property, and power remains questionable.

\section{Concluding remarks}

The emergence of BRICS as a group of emerging economies that are relatively dominant within their regions has seen the reconfiguration of agro-food systems and agrarian relations. This collection shows how this is evident in BRICS themselves, but also increasingly in the MICs and in their respective regions of influence. However, what are often touted as forms of South-South cooperation do not necessarily present alternative development pathways to those promoted by investors from the global North, or from development agencies or international financial institutions. There is, though, a clear pattern of capital from BRICS countries on the move, often seeking to replicate their own models of production, processing, and trade - not always with success. While cooperative relations among the BRICS countries are growing, the pattern of development is not necessarily distinct. Rather, there is a general pattern of extractivism, large-farm development often through contested land deals or 'land grabbing, the expansion of corporate agribusiness and agro-processing, consolidated and vertically integrated value chains, right through to the supermarketisation of food retail. In important ways, then, in order to understand the changing global agro-food system, one needs to engage with the critical ways in which BRICS countries - as states, private capital, and even as a source of labour - are reshaping food systems. This collection aims to provide valuable insights into these changing global dynamics of agrarian change and contributes to the debates regarding the rise of BRICS and its implications for global agrarian transformation.

\section{Disclosure statement}

No potential conflict of interest was reported by the authors.

\section{Acknowledgments}

This collection is a result of several international conferences organised by BRICS Initiatives in Critical Agrarian Studies (BICAS). We would like to thank all those who participated in the conferences for their input on earlier versions of these papers. We would also like to thank Jun Borras for encouraging us to pursue this collection. Finally, a special thanks to Madeleine Hatfield for her help throughout this process and for going above and beyond her tasks as Journal Manager. 


\section{Notes on contributors}

Ben M. McKay is an assistant professor of Development and Sustainability at the University of Calgary in Canada. He received his $\mathrm{PhD}$ from the International Institute of Social Studies (ISS) in The Hague, Netherlands, and is a research associate and part of the global secretariat of the BRICS Initiatives in Critical Agrarian Studies (BICAS). He is currently researching the rise of BRICS countries and its implications for global agrarian transformation, with a particular focus on the extractive dynamics of industrial capitalist agriculture. His work has been published in the Journal of Peasant Studies, World Development, Canadian Journal of Development Studies, Energy Policy, among others.

Ruth Hall is a professor at the Institute for Poverty, Land and Agrarian Studies (PLAAS) at the University of the Western Cape, South Africa. She holds a DPhil in Politics and International Relations from the University of Oxford, and has published several books on land reform and agrarian change in South Africa and broader trends of land grabbing in Africa. Her latest book is Africa's land rush: livelihoods and agrarian change (James Currey, 2015, ed. with Ian Scoones and Dzodzi Tsikata). She is a co-founder of the Land Deal Politics Initiative and the BRICS Initiative in Critical Agrarian Studies, and coordinates the work of the Future Agricultures Consortium in Southern Africa.

Juan Liu is an assistant professor at College of Humanities and Social Development, Northwest A\&F University, China, and a postdoctoral researcher at ICTA, Universitat Autónoma de Barcelona. She is in the global secretariat of the BRICS Initiatives for Critical Agrarian Studies (BICAS) and is co-editor of the BICAS Working Paper Series. She holds a $\mathrm{PhD}$ in Development Studies from China Agricultural University, and completed a Postdoc at the International Institute of Social Studies (ISS) in The Hague, Netherlands. Her research interests and publications include: internal migration and left-behind population, social policies, rural politics, land politics, and political economy of agriculture, food and environment.

\section{Notes}

1. Alden, China in Africa; Bond, "BRICS"; Gray and Gills, "South-South Cooperation and the Rise of the Global South".

2. See, e.g. the Institute of Development Studies"Rising Powers in International Development Programme'; Scoones,'New Development Encounters'; Alden, China in Africas; Brautigam and Tang,"China's Engagement in African Agriculture"; Carmody and Taylor,"Flexigemony and Force in China's Geoeconomic Strategy in Africa".

3. See www.iss.nl/bicas; www.plaas.org.za/bicas

4. For an analysis on the big picture of BRICS as a group in the international context see Nayyar, "BRICS, Developing Countries and Global Governance".

5. Andrade, "Export or Die".

6. Ibid.

7. World Bank, "Awakening Africa's Sleeping Giant".

8. Nikulin and Trotsuk, "Utopian Visions of Contemporary Rural-urban Russia".

9. See Levien, "The Land Question".

10. Weis, "Accelerating Biophysical Contradictions". 
11. See, e.g. Alonso-Fradejas, "Anything but a Story Foretold"; McKay, "Agrarian Extractivism in Bolivia"; Petras and Veltmeyer, "Agro-Extractivism".

12. See Edelman et al., "Global Land Grabs".

13. See Galeano,"Paraguay and the Expansion of Brazilian and Argentinian Agribusiness

Frontiers"; Urioste, "Concentration and Foreignisation".

14. Hall, "Land Grabbing in Southern Africa”.

15. Martiniello, "Don't Stop the Mill".

16. Ibid.

17. Hall, "Land Grabbing in Southern Africa," 207.

18. See Hofman and Ho,"China's'Developmental Outsourcing”; Lu,“Tapping into Rubber”;

Thomas, "Going Out"; and Borras et al., "Land Control and Crop Booms".

19. Zhou, "Chinese Agrarian Capitalist".

20. Borras et al.,"Land Grabbing in Latin America,"862; see also McKeon, Food Security

Governance; on food regime analysis see Friedmann and McMichael, "Agriculture and the State System"; McMichael, "A Food Regime Genealogy".

21. Friedmann, "The Political Economy of Food", 30, 31.

22. Oliveira and Hecht,"Sacred Groves, Sacrifice Zones and Soy Production". Pools de siembra refer to the pooling of resources by farm management companies in order to achieve economic of scale through input purchases, storage and processing facilities and to increase bargaining power.

23. See also Wesz, "Strategies and Hybrid Dynamics".

24. Campbell, "South African Supermarket Expansion in sub-Saharan Africa".

25. Milhorance, "Growing South-South Agribusiness Connections".

26. See Ruckert et al., "Post-neoliberalism in Latin America".

27. See Ban and Blyth, "The BRICs and the Washington Consensus".

28. McKay et al., "China and Latin America".

29. Wilkinson et al., "Brazil and China".

\section{ORCID}

Ben M.McKay http://orcid.org/oooo-0oo2-5737-5255 


\section{Bibliography}

Alden, C. China in Africa: Partner, Competitor or Hegemon?. London: Zed Books, 2007.

Alonso-Fradejas, A. "Anything but a Story Foretold: Multiple Politics of Resistance to the Agrarian Extractivist Project in Guatemala_." Journal of Peasant Studies 42, no. 3-4 (2016): 489-515.

Andrade, D. "Export or Die': The Rise of Brazil as an Agribusiness Powerhouse_-" Third World Thematics 1, no. 5 (2017): 653-672.

Ban, C., and M. Blyth. "The BRICs and the Washington Consensus: An Introduction_"Review of International Political Economy 20, no. 2 (2013): 241-255.

Bond, P. "BRICS: “Anti-imperialist' or 'Sub-imperialist'?_" Links International Journal of Socialist Renewal (2013). https://links.org.au/node/3265.

Borras Jr, S. M., J. C. Franco, S. Gomez, C. Kay, and M. Spoor. "Land Grabbing in Latin America and the Caribbean_." The Journal of Peasant Studies 39, no. 3-4 (2012): 845-872.

Borras Jr, S. M., J. Liu, Z. Hu, H. Li, C. Wang, Y. Xu, J. Franco, and J. Ye. "Land Control and Crop Booms - Inside China: Implications for How We Think of the Current Global Land Rush.” Globalizations, Forthcoming.

Brautigam, D., and X. Tang."China's Engagement in African Agriculture:'Down to the Countryside." The China Quarterly 199 (2009): 686-706.

Campbell, M. "South African Supermarket Expansion in Sub-Saharan Africa." Third World Thematics 1, no. 5 (2017): 709-725.

Carmody, P., and I. Taylor. "Flexigemony and Force in China's Geoeconomic Strategy in Africa: Sudan and Zambia Compared." Geopolitics 15, no. 3 (2010): 496-515.

Edelman, M., C. Oya, and S. M. Borras Jr. "Global Land Grabs: Historical Processes, Theoretical and Methodological Implications and Current Trajectories." Third World Quarterly 34, no. 9 (2013): 1517-1531.

Friedmann, H. "The Political Economy of Food: A Global Crisis." New Left Review 197 (1993): 29-57. Friedmann, H., and P. McMichael."Agriculture and the State System." Sociologia Ruralis 29, no. 2 (1989): 93-117.

Galeano, L. A. "Paraguay and the Expansion of Brazilian and Argentinian Agribusiness Frontiers." Canadian Journal of Development Studies/Revue Canadienne D'études Du Développement 33, no. 4 (2012): 458-470.

Gray, K., and B. K. Gills."South-South Cooperation and the Rise of the Global South."Third World Quarterly 37, no. 4 (2016): 557-574.

Hall, R. "Land Grabbing in Southern Africa: The Many Faces of the Investor Rush." Review of African Political Economy 38, no. 128 (2011): 193-214.

Hofman, I., and P. Ho. "China's 'Developmental Outsourcing': A Critical Examination of Chinese Global 'Land Grabs' Discourse.” Journal of Peasant Studies 39, no. 1 (2012): $1-48$.

Levien, M. "The Land Question: Special Economic Zones and the Political Economy of Dispossession in India." Journal of Peasant Studies 39, no. 3-4 (2012): 933-969.

Lu, J. N. "Tapping into Rubber: China's Opium Replacement Program and Rubber Production in Laos." The Journal of Peasant Studies (2017): 1-22. doi:10.1080/03066150.2017.1314268. 
Martiniello, G."'Don't Stop the Mill': South African Capital and Agrarian Change in Tanzania."Third World Thematics 1, no. 5 (2017): 633-652.

McKay, B. M. "Agrarian Extractivism in Bolivia.” World Development 97 (2017): 199-211.

McKay, B. M., A. Alonso-Fradejas, Z. W. Brent, S. Sauer, and Y. Xu. "China and Latin America: Towards a New Consensus of Resource Control?” Third World Thematics 1, no. 5 (2017): 592-611.

McKeon, N. Food Security Governance: Empowering Communities, Regulating Corporations. New York: Rouftledge, 2015.

McMichael, P. “A Food Regime Genealogy.” The Journal of Peasant Studies 36, no. 1 (2009): 139-169. Milhorance, C. "Growing South-South Agribusiness Connections: Brazil's Policy Coalitions Reach Southern Africa." Third World Thematics 1, no. 5 (2017): 691-708.

Nayyar, D.“BRICS, Developing Countries and Global Governance.”Third World Quarterly 37, no. 4 (2016): 575-591.

Nikulin, A. M., and I. V. Trotsuk. "Utopian Visions of Contemporary Rural-urban Russia." Third World Thematics 1, no. 5 (2017): 673-690.

Oliveira, G. de L. T., and Susanna Hecht."Sacred Groves, Sacrifice Zones and Soy Production: Globalization, Intensification and Neo-nature in South America." The Journal of Peasant Studies 43, no. 2 (2016): 251-285.

Petras, J., and H. Veltmeyer."Agro-Extractivism: The Agrarian Question of the 21st Century."In Extractive Imperialism in the Americas, edited by J. Petras and H. Veltmeyer, 62100. Leiden: Brill, 2014.

Ruckert, A., L. Macdonald, and K. R. Proulx."Post-Neoliberalism in Latin America: A Conceptual Review." Third World Quarterly 38, no. 7 (2017): 1583-1602.

Scoones, I., L. Cabral, and H. Tugendhat. "New Development Encounters: China and Brazil in African Agriculture." IDS Bulletin 44, no. 4 (2013): 1-19.

Thomas, N. "Going out: China's Food Security from Southeast Asia." The Pacific Review 26, no. 5 (2013): 531-562. doi:10.1080/09512748.2013.842313.

Urioste, M. "Concentration and 'Foreignization' of Land in Bolivia." Canadian Journal of Development Studies/Revue Canadienne D'études Du Développement 33, no. 4 (2012): 439-457.

Weis, T. "The Accelerating Biophysical Contradictions of Industrial Capitalist Agriculture." Journal of Agrarian Change 10, no. 3 (2010): 315-341.

Wesz Jr, V. J. "Strategies and Hybrid Dynamics of Soy Transnational Companies in the Southern Cone." The Journal of Peasant Studies 43, no. 2 (2016): 286-312.

Wilkinson, J., V. J. Wesz Junior, and A. R. M. Lopane. "Brazil and China: The Agribusiness Connection in the Southern Cone Context." Third World Thematics 1, no. 5 (2017): $726-745$.

Zhou, J. "Chinese Agrarian Capitalism in the Russian Far East." Third World Thematics 1, no. 5 (2017): 612-632. 